\title{
Discutindo Doenças Prevalentes na Infância e Suas Ações em Saúde: Relato de Experiência
}

\author{
Soares, Lorena Sousa; Bezerra, Maria Augusta Rocha; Santos, Janaina Maria dos \\ Universidade Federal do Piauí — Iorenacacaux@hotmail.com
}

Introdução: As doenças prevalentes na infância são abordadas a partir da leitura e da discussão do protocolo de Atenção às Doenças Prevalentes da Infância (AIDPI) e, mais recentemente, ações voltadas à assistência em saúde aos recém-nascidos foram padronizadas no AIDPI Neonatal. Objetivo: Este trabalho apresenta como objetivo relatar a experiência da discussão promovida entre os discentes sobre as doenças prevalentes da infância e suas principais ações em saúde. Métodos: a discussão sobre a temática foi desenvolvida na disciplina de Enfermagem na Saúde da Criança e do Adolescente , durante um turno (manhã), no mês de dezembro de 2013. a turma foi dividida em seis grupos designados a estudar, pesquisar e expor, em sala de aula, determinados assuntos do AIDPI e AIDPIneo. Houve a presença de duas monitoras da disciplina auxiliando, previamente, o desenvolvimento desta atividade. Resultados: Cada grupo teve 15 minutos para expor, brevemente, os principais pontos do seu tema. Os temas escolhidos pela facilitadora (docente) foram: avaliação e classificação dos principais sinais e sintomas de riscos; indicações de tratamento; aconselhamento e ensinamentos à mãe e acompanhante. Os discentes usaram as mais variadas metodologias de aprendizagem: panfletos, cartazes, slides e dramatização. Além disso, a cada apresentação, a facilitadora colocava questões norteadoras para estimular as discussões, interrelacionando com a realidade social e de saúde local. Os discentes participaram ativamente das discussões, expondo dúvidas e vivências próprias diante de determinadas situações, além disso, colocavam propostas de ações em saúde para cada questão, planejando, assim, as funções e intervenções ativas nas aulas práticas da referida disciplina, que iriam acontecer posteriormente e requeriam conhecimento prévio sobre o AIDPI e AIDPIneo. Conclusões: o momento foi rico e de vasto aprendizado, pois os discentes utilizaram, de forma bem pessoal e intimista, abordagens didáticas e claras de aprendizagem. com os panfletos e cartazes, pôde-se perceber uma linguagem clara e bem próxima à população atendida na realidade de saúde local, além disso, com a dramatização, todos puderam vivenciar ainda mais, de forma realística, pontos abordados no AIDPI. As discussões desenvolvidas foram marcadas por questionamentos e soluções às variadas demandas de saúde em neonatologia e pediatria.

Soares, Lorena Sousa; Bezerra, Maria Augusta Rocha; Santos, Janaina Maria dos. Discutindo Doenças Prevalentes na Infância e Suas Ações em Saúde: Relato de Experiência. In: Anais do Congresso Internacional de Humanidades \& Humanização em Saúde [= Blucher Medical Proceedings, num.2, vol.1]. São Paulo: Editora Blucher, 2014. ISSN 2357-7282

DOI 10.5151/medpro-cihhs-10285 